\title{
Peran Pasien dan Keluarga dalam Upaya Mencegah Bahaya dan Kejadian Tidak Diharapkan untuk Menjaga Keselamatan Pasien di Rumah Sakit
}

\author{
Novi Pratiwi \\ novipratiwi211@gmail.com
}

\begin{abstract}
Abstrak
Rumah sakit sebagai tempat yang sangat kompleks dengan ratusan macam obat, ratusan tes dan prosedur, banyak terdapat alat dan teknologi, bermacam profesi yang memberikan pelayanan pasien selama 24 jam secara terus-menerus, dimana keberagaman dan kerutinan pelayanan tersebut apabila rumah sakit tidak dikelola dengan baik dapat menimbulkan Kejadian Tidak Diharapkan (KTD/Adverse events) yang sangat mengancam keselamatan pasien. Keselamatan pasien (patient safety) adalah suatu sistem dimana rumah sakit membuat asuhan pasien lebih aman dalam upaya mencegah terjadinya cidera yang disebabkan oleh kesalahan akibat melaksanakan suatu tindakan atau tidak mengambil tindakan yang seharusnya diambil. Keselamatan pasien (patient safety) diharapkan dapat dijadikan sebagai budaya dalam rumah sakit untuk mewujudkan keselamatan baik bagi pasien ataupun keluarga dan keselamatan pekerja atau petugas kesehatan. Disamping perawat dan dokter, keluarga juga menjadi salah satu faktor yang mempengaruhi keselamatan pasien (patient safety).
\end{abstract}

Kata kunci : Keselamatan pasien, Kejadian Tidak Diharapkan (KTD), Pasien dan keluarga.

\section{Latar Belakang}

Rumah sakit merupakan layanan jasa yang memiliki peran penting dalam kehidupan masyarakat dalam bidang kesehatan. Sebagai tempat yang sangat kompleks dengan ratusan macam obat, ratusan tes dan prosedur, banyak terdapat alat dan teknologi, bermacam profesi yang memberikan pelayanan pasien selama 24 jam secara terus-menerus, dimana keberagaman dan kerutinan pelayanan tersebut apabila rumah sakit tidak dikelola dengan baik dapat menimbulkan Kejadian Tidak Diharapkan (KTD/Adverse events) yang sangat mengancam keselamatan pasien.

Keselamatan pasien (patient safety) adalah suatu sistem dimana rumah sakit membuat asuhan pasien lebih aman dalam upaya mencegah terjadinya cidera yang disebabkan oleh kesalahan akibat melaksanakan suatu tindakan atau tidak mengambil tindakan yang seharusnya diambil. Berdasarkan Peraturan Menteri Kesehatan Republik Indonesia Nomor 11 Tahun 2017, keselamatan pasien merupakan suatu sistem yang membuat asuhan pasien lebih aman, meliputi 
asesmen risiko, identifikasi dan pengelolaan risiko pada pasien, pelaporan dan analisis insiden, kemampuan belajar dari insiden dan tindaklanjutnya, serta implementasi solusi untuk meminimalkan timbulnya risiko juga mencegah terjadinya cidera yang disebabkan kesalahan akibat melaksanakan suatu tindakan atau tidak mengambil tindakan yang seharusnya diambil.

Keselamatan pasien (patient safety) diharapkan dapat dijadikan sebagai budaya dalam rumah sakit untuk mewujudkan keselamatan baik bagi pasien ataupun keluarga dan keselamatan pekerja atau petugas kesehatan.

Perilaku perawat dengan kemampuan perawat sangat berperan penting dalam pelaksanaan keselamatan pasien. Perilaku yang tidak aman, lupa, kurangnya perhatian/motivasi, kecerobohan, tidak teliti dan kemampuan yang tidak memperdulikan dan menjaga keselamatan pasien berisiko untuk terjadinya kesalahan dan akan mengakibatkan cedera pada pasien, berupa Near Miss (Kejadian Nyaris Cedera/KNC) atau Adverse Event (Kejadian Tidak Diharapkan/KTD). Maka selanjutnya pengurangan kesalahan dapat dicapai dengan memodifikasi perilaku perawat menjadi lebih baik.

Untuk menjaga keselamatan pasien ini, baik pasien ataupun keluarga sebagai partner di pelayanan kesehatan juga memiliki peran yang sangat penting dalam upaya mencegah bahaya dan kejadian tidak diharapkan untuk menjaga keselamatan pasien. Pasien dan keluarga diharapkan dapat memberikan informasi yang benar, jelas, lengkap dan jujur tentang pasien dan mematuhi seluruh aturan yang ada di rumah sakit.

\section{Metode}

Metode yang dilakukan dalam penulisan ini adalah metode kepustakaan yaitu dengan melakukan peninjauan, mengumpulkan data-data dan menganalisisnya yang diperoleh dari buku, e-book, jurnal-jurnal terkini ataupun sumber informasi lainnya yang memuat informasi pembahasan tentang peran pasien dan keluarga dalam upaya mencegah bahaya dan adverse events (Kejadian Tidak Diharapkan) untuk menjaga keselamatan pasien di rumah sakit. Pengolahan data dilakukan mulai dari menganalisis isi buku dan jurnal atau sumber informasi lainnya yang berhubungan dengan peran pasien dan keluarga dalam upaya mencegah bahaya dan adverse events (Kejadian Tidak Diharapkan) untuk menjaga keselamatan pasien di rumah sakit hingga kesimpulan dari penulis.

\section{Hasil}

Keselamatan pasien di rumah sakit menjadi isu penting karena banyaknya kasus Medical Error yang terjadi di berbagai Negara. Setiap tahun di Amerika hampir 100.000 pasien yang 
dirawat di rumah sakit meninggal karena Medical Error. Dalam penelitian yang dilakukan oleh Cahyono (2012), membuktikan bahwa kematian akibat cidera medis 50\% diantaranya sebenarnya dapat dicegah. Sekitar tahun 2000 Institut of Medicine (IOM) Amerika Serikat menerbitkan laporan "To Err is Human, Building to Safer Health System” yang menyebutkan bahwa rumah sakit di Utah dan Colorado ditemukan KTD sebesar 2,9\% dan 6,6\% diantaranya meninggal, sedangkan di New York ditemukan KTD 3,7\% KTD dan 13,6\% diantaranya meninggal. Selanjutnya, angka kematian akibat KTD pada pasien rawat inap di Amerika Serikat berjumlah 33,6 juta per tahun berkisar 44.000 jiwa sampai 98.000 jiwa. Selain itu, publikasi WHO tahun 2004 menyatakan KTD dengan rentang 3,2 - 16,6\% pada rumah sakit di berbagai negara yaitu Amerika, Inggris, Denmark dan Australia.

Selanjutnya, diperoleh informasi bahwa sekitar 1.292 Rumah Sakit (RS) di Indonesia yang telah terakreditasi $(60 \%)$, belum semuanya menerapkan standar keselamatan pasien secara optimal. Indikator untuk keselamatan pasien (KP) diantaranya adalah jumlah insiden yang terjadi, baik KNC atau KTD. Data insiden KP yang tercatat pada bulan September 2006Agustus 2007, dari 9 provinsi terdapat 145 insiden KP yang dilaporkan, dengan angka terbanyak DKI Jakarta, Jawa Tengah, dan Yogyakarta. Secara nasional angka insiden KP ini sulit dilacak, mengingat masih belum membudayanya sistem pelaporan insiden KP di RS.

Standar sasaran keselamatan pasien telah disusun oleh KARS 2012 yaitu sebagai berikut:

a. Sasaran I : Ketepatan identifikasi pasien

b. Sasaran II : Peningkatan komunikasi yang efektif

c. Sasaran III : Peningkatan keamanan obat yang perlu diwaspadai (high alert)

d. Sasaran IV : Kepastian tepat-lokasi tepat-prosedur tepat-pasien operasi

e. Sasaran V : Pengurangan risiko infeksi terkait pelayanan kesehatan

f. Sasaran VI : Pengurangan risiko pasien jatuh

Mengacu kepada standar keselamatan pasien, maka rumah sakit harus mendesain (merancang) proses baru atau memperbaiki proses yang ada, memonitor dan mengevaluasi kinerja melalui pengumpulan data, menganalisis secara intensif Kejadian Tidak Diharapkan (KTD), dan melakukan perubahan untuk meningkatakan kinerja serta keselamatan pasien.

Disamping perawat dan dokter, ternyata keluarga juga menjadi salah satu faktor yang mempengaruhi keselamatan pasien (patient safety). Oleh sebab itu sangat diharapkan peran keluarga selama pasien di rawat di rumah sakit. Keluarga merupakan bagian dari tim pengobatan dan perawatan. Terlebih lagi di Indonesia dengan kultur sosial yang tinggi ditambah keterbatasan jumlah perawat di rumah sakit sehingga dibutuhkannya peran keluarga 
dalam menjamin keselamatan pasien. Maka dari itu, perlu diberikan pendidikan kesehatan pada keluarga pasien mengenai langkah-langkah tentang keselamatan pada pasien.

\section{Pembahasan}

Keselamatan pasien (patient safety) adalah suatu sistem dimana rumah sakit membuat asuhan pasien lebih aman dalam upaya mencegah terjadinya cidera yang disebabkan oleh kesalahan akibat melaksanakan suatu tindakan atau tidak mengambil tindakan yang seharusnya diambil.

Peran keluarga dalam menjaga keselamatan pasien dipelayanan kesehatan yaitu:

1. Memberikan informasi yang benar, jelas, lengkap dan jujur tentang pasien

2. Mengetahui dan melaksanakan kewajiban serta tanggung jawab pasien maupun keluarga

3. Mengajukan pertanyaan-pertanyaan untuk hal yang tidak dimengerti kepada tenaga kesehatan

4. Memahami dan menerima konsekuensi pelayanan kesehatan

5. Mematuhi dan menghormati peraturan rumah sakit

6. Memperlihatkan sikap menghormati dan tenggang rasa dalam proses bersama tim kesehatan mengelola pasien

7. Memenuhi kewajiban finansial yang telah disepakati.

Adapun penerapan enam sasaran keselamatan pasien dan peran keluarga dalam menjaga keselamatan pasien di pelayanan kesehatan yaitu:

1) Ketepatan Identifikasi Pasien

Pasien dalam keadaan tidak sadar, gelisah, mengalami gangguan penglihatan, gangguan pendengaran, gangguan proses pikir, mendapat obat bius, atau gangguan lain tidak mampu melakukan identifikasi diri dengan benar. Selain itu pasien yang pindah ruang rawat atau bertukar tempat tidur saat perawatan di rumah sakit berisiko mengalami ketidaktepatan identifikasi, maka rumah sakit menyusun sistem untuk memastikan identifikasi pasien sebagai individu yang akan menerima pelayanan adalah tepat dan jenis pelayanan atau pengobatan terhadap individu tersebut adalah sesuai.

Peran pasien dan keluarga untuk memastikan ketepatan identifikasi pasien adalah:

- Memberikan data diri yang tepat pada saat mendaftar sesuai dokumen data diri yang dimiliki.

- Selama rawat inap pasien dipakaikan gelang. Pasien dan keluarga harus memahami fungsi gelang dan patuh menggunakan gelang tersebut selama rawat inap karena gelang 
tersebut dipakai oleh tim kesehatan guna memastikan kebenaran identitas dan faktor risiko pasien saat memberikan pelayanan.

- Pasien atau keluarga kooperatif saat dilakukan verifikasi identitas oleh petugas saat akan melakukan tindakan, memberikan obat, mengambil preparat untuk pemeriksaan laboratorium dan lain-lain

\section{2) Komunikasi Efektif}

Pasien yang menjalani rawat inap dikelola oleh dokter dan berbagai profesi lain sebagai tim dengan menerapkan sistem komunikasi yang efektif untuk memberikan pelayanan.

Peran pasien dan keluarga mewujudkan komunikasi efektif adalah:

- Menunjuk atau menetapkan anggota keluarga yang diberi kewenangan untuk berkomunikasi dengan tim kesehatan. Penunjukkan ini diperlukan untuk memastikan komunikasi berlangsung efektif dan berkesinambungan, tidak mengalami rantai komunikasi yang panjang dan kompleks yang berisiko menyebabkan perubahan makna isi informasi.

- Memberikan informasi dan data terkait kondisi pasien kepada tim kesehatan dengan benar dan jelas.

- Memberikan informasi pada tenaga kesehatan bila ada kejadian tidak diharapkan.

- Meminta informasi yang diperlukan kepada tim kesehatan

3) Pemberian Obat secara Aman

Pemberian obat merupakan bagian yang mengambil porsi dominan dalam tata kelola pasien rawat inap. Peran serta keluarga dalam menjamin keamanan pemberian obat adalah:

- Memberikan informasi yang lengkap tentang riwayat obat yang pernah dikonsumsi sebelum masuk rumah sakit

- Memberikan informasi tentang riwayat alergi atau reaksi yang dialami saat menggunakan obat tertentu

- Mendukung pengawasan pemberian obat selama rawat inap dengan cara memastikan identitas pasien benar, menanyakan jenis obat yang diberikan, tujuan pemberian, dosis dan waktu pemberian obat.

4) Kepastian Tepat-Lokasi, Tepat-Prosedur, Tepat-Pasien Operasi

Salah satu prosedur yang dilakukan sebelum tindakan operasi adalah proses verifikasi. Peran pasien dan keluarga dalam proses verifikasi praoperasi adalah memberikan informasi yang benar dan bekerja sama secara kooperatif. Proses yang dilakukan meliputi: 
- Verifikasi lokasi, prosedur, dan pasien yang benar. Proses ini dilakukan dengan membuat tanda pada lokasi yang dioperasi. Penandaan lokasi operasi ini melibatkan pasien, dibuat oleh dokter yang akan melakukan tindakan dan dilaksanakan saat pasien dalam keadaan sadar. Tanda ini tidak boleh dihapus dan harus terlihat sampai saat akan disayat

- Memastikan bahwa semua dokumen, foto, hasil pemeriksaan yang relevan tersedia, diberi label dengan baik

- Melakukan verifikasi ketersediaan peralatan khusus yang dibutuhkan.

5) Pengurangan risiko infeksi terkait pelayanan kesehatan

Rumah sakit merupakan tempat yang memungkinkan berkumpulnya berbagai jenis kuman sedangkan pasien yang sedang dirawat memiliki daya tahan tubuh relatif rendah. Dengan demikian diperlukan suatu proses bersama untuk mencegah timbulnya infeksi lain yang tidak berhubungan dengan penyakit utama pasien.

Peran pasien dan keluarga dalam pengurangan risiko terkait pelayanan kesehatan adalah:

- Menerapkan prosedur cuci tangan yang benar

Keluarga memiliki kemungkinan sering kontak dengan pasien, maka untuk melindungi diri sendiri dan melindungi pasien dari perpindahan kuman disarankan keluarga menerapkan prosedur cuci tangan yang benar pada 5 momen yaitu saat sebelum kontak dengan pasien, sesudah kontak pasien, sesudah ke toilet, sebelum dan sesudah makan.

Lingkungan sekitar pasien berisiko terpapar kuman maka disarankan untuk mencuci tangan sesudah kontak dengan lingkungan pasien (meja, alat tenun, tempat tidur dsb). Guna memperoleh hasil cuci tangan yang optimal, pasien dan keluarga disarankan mencermati dan mengikuti petunjuk 6 langkah mencuci tangan yang diberikan oleh petugas kesehatan atau panduan cuci tangan yang ada di rumah sakit.

- Membatasi pengunjung pasien

Selama pasien dirawat di rumah sakit, hendaknya pasien tidak berinteraksi dengan banyak orang karena berisiko terpapar kuman dari pengunjung dalam keadaan pertahanan diri yang relatif rendah, dengan demikian peran keluarga diperlukan untuk membatasi pengunjung yang kontak dengan pasien

- Menerapkan etika batuk yang benar

Keluarga dan pengunjung yang batuk berisiko menyebarkan kuman melalui partikel halus di udara, dengan demikian bila sedang mengalami batuk keluarga perlu menggunakan masker atau menerapkan tehnik perlindungan yang benar saat batuk yaitu menutup mulut dan hidung menggunakan lengan. 
6) Pengurangan Risiko Pasien Jatuh

Individu yang sedang sakit memiliki keterbatasan dalam pengamanan diri termasuk menghindari jatuh. Rumah sakit mengambil tindakan untuk mengurangi risiko dengan melakukan pengkajian faktor-faktor yang dapat menyebabkan jatuh, seperti penggunaan obat, gaya jalan dan keseimbangan, alat bantu berjalan yang digunakan oleh pasien, riwayat jatuh saat berjalan atau saat istirahat baring di tempat tidur.

Peran pasien dan keluarga dalam mencegah pasien jatuh saat dirawat di rumah sakit adalah:

- Memastikan bahwa penanda pasien beresiko jatuh berupa gelang kuning dipakai pasien

- Jangan melepas atau memindah kartu kuning yang dipasang petugas kesehatan dekat tempat tidur pasien atau di depan kamar pasien karena kartu tersebut merupakan penanda untuk mewaspadai pasien yang beresiko jatuh

- Keluarga atau pasien perlu memastikan diri untuk memahami informasi yang diberikan oleh petugas kesehatan agar dapat mendukung tindakan pencegahan jatuh. Adapun informasi yang perlu diketahui adalah faktor resiko jatuh yang teridentifikasi seperti obat yang dipergunakan, kesadaran pasien, keseimbangan saat berjalan, dll, tindakan pencegahan jatuh yang perlu dilakukan, cara untuk minta bantuan, cara menggunakan bel atau sarana komunikasi di ruangan, cara mengatur pengamanan tempat tidur, pengggunaan tali pengaman, dll.

\section{Penutup}

\section{Kesimpulan dan Saran}

Keselamatan pasien (patient safety) adalah suatu sistem dimana rumah sakit membuat asuhan pasien lebih aman dalam upaya mencegah terjadinya cidera yang disebabkan oleh kesalahan akibat melaksanakan suatu tindakan atau tidak mengambil tindakan yang seharusnya diambil. Sistem yang dimaksud meliputi penilaian risiko, identifikasi dan pengelolaan hal yang berhubungan dengan resiko pasien, pelaporan dan analisis insiden dan tindaklanjutnya serta implementasi solusi untuk meminimalkan timbulnya risiko.

Selain dokter dan perawat, pasien ataupun keluarga sebagai partner di pelayanan kesehatan juga memiliki peran yang sangat penting dalam upaya mencegah bahaya dan kejadian tidak diharapkan untuk menjaga keselamatan pasien. Pasien dan keluarga diharapkan dapat memberikan informasi yang benar, jelas, lengkap dan jujur tentang pasien dan mematuhi seluruh aturan yang ada di rumah sakit. 


\section{Daftar Pustaka}

Al-asaf, A. F. (2013). Mutu pelayanan kesehatan: Perspektif internasional. Jakarta: EGC.

Azizah, S. D. \& Rachmawati, E. (2016). Analisis determinan kejadian nyaris cedera dan kejadian tidak diharapkan di Instalasi Gizi RS Anak dan Bunda Harapan Kita. JUKEMA, 2(1), 58-67.

Cahyono, J. B. \& Suhardjo, B. (2012). Membangun budaya keselamatan pasien dalam praktek kedokteran. Yogyakarta: Kanisius.

Ibrahim, H., Damayanti, D. S., Amansyah, M., \& Sunandar. (2017). Gambaran penerapan standar manajemen keselamatan dan kesehatan kerja rumah sakit di RSUD Haji Makassar. Al-Sihah : Public Health Science Journal, 9(2), 160-173.

Ismainar, H. (2015). Keselamatan pasien di rumah sakit. Yogyakarta: Deepublish.

KARS. (2012). Kebijakan standar akreditasi RS (Versi 2012) dan cara penilaiannya. Jakarta: Komisi Akreditasi Rumah Sakit.

Lombogia, A., Rottie, J., \& Karundeng, M. (2016). Hubungan perilaku dengan kemampuan perawat dalam melaksanakan keselamatan pasien (patient safety) di ruang akut Instalasi Gawat Darurat RSUP Prof. DR. R. D. Kandou Manado. e-journal Keparawatan (e-Kp), $4(2), 1-8$.

Salawati, L. (2020). Penerapan keselamatan pasien rumah sakit. Jurnal Averrous, 6(1), 98-107.

Simamora, R. H. (2019). Buku ajar pelaksanaan identifikasi pasien. Uwais Inspirasi Indonesia.

Tutiany, Lindawati, \& Krisanti, P. (2017). Manajemen keselamatan pasien. Jakarta: Kementerian Kesehatan Republik Indonesia.

Wardhani, V. (2017). Buku ajar manajemen keselamatan pasien. Malang: UB Press. 